39. Artman $\mathrm{M} 1991$ Determination of $\mathrm{Na}^{+} \cdot \mathrm{Ca}^{2+}$ exchanger and $\mathrm{Na}^{+}$-dependent $\mathrm{Ca}^{2+}$ uptake in cardiac sarcolemma from fetal, newborn, immature, and adult rabbits. Circ 84(suppl II):II-188(abstr)

40. Andeson PAW Oakeley AE 1989 Immunological identification of five troponin $\mathrm{T}$ isoforms reveals an elaborate maturational troponin $\mathrm{T}$ profile in rabbit myocardium. Circ Res 65:1087-1093
41. Saggin L, Gorza LG, Ausoni S, Schiaffino S 1989 Troponin I switching in the developing heart. J Biol Chem 264:16299-16302

42. Lompre AM, Mercadier JJ, Wisnewsky C, Bouveret P, Pantaloni C, D'Albis A, Schwartz K 1981 Species and age-dependent changes in relative amounts of cardiac myosin isoenzymes in mammals. Dev Biol 84:286-290

\title{
Announcement
}

\section{4th International Meeting on Trace Elements in Medicine and Biology}

The 4th International Meeting on Trace Elements in Medicine and Biology, "Trace Elements and Free Radicals in Oxidative Diseases," will be held in Chamonix, France, April 5-9, 1993. The meeting is organized by the Society for Free Radical Research, the Sociéte Francophone d'Etude et de Recherche sur les Elements Trace Essentiels, and the Club d'Etude sur les Radicaux Libres. For registration information, contact: Professeur Alain Favier or Madame Arlette Alcaraz, Laboratoire de Biochimie C, Hôpital A. Michallon, B.P. 217X, 38043 Grenoble, Cédex 09, France, phone (33) 767654 07; FAX (33) 76426644. 